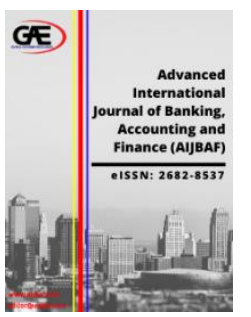

\author{
ADVANCED INTERNATIONAL JOURNAL OF \\ BANKING, ACCOUNTING AND FINANCE \\ (AIJBAF) \\ www.aijbaf.com
}

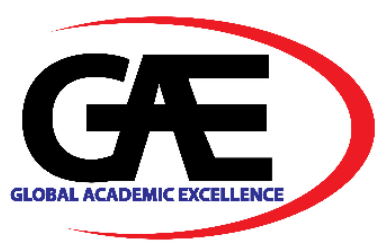

\title{
THE ETHICAL PERFORMANCE AND PRIMACY OF ACCOUNTANT PROFESSIONAL MORAL
}

\author{
Wiwik Pratiwi $^{1^{*}}$, Wahyu Wibowo ${ }^{2}$ \\ 1 Study Program of Accounting, Sekolah Tinggi Ilmu Ekonomi YAI, Jakarta, Indonesia \\ Email: pratiwi_wiwik@yahoo.com \\ 2 The faculty of language and literature, Universitas Nasional Jakarta, Indonesia \\ Email: kangbowie@gmail.com \\ Corresponding Author
}

\section{Article Info:}

Article history:

Received date:08.06.2020

Revised date: 07.07.2020

Accepted date: 10.08 .2020

Published date: 10.09.2020

\section{To cite this document:}

Pratiwi, W., \& Wobowo, W. (2020). The Ethical Performance and Primary of Accountant Professional Moral. Advanced International Journal of Banking, Accounting, and Finance, 2 (4), 10-24.

DOI: $10.35631 /$ AIJBAF.24002.

\begin{abstract}
:
This study aims to clarify the ethical role of an accountant who has their possessing moral eminence by reanalyzed some of the current cases of breaking ethics in Indonesia that have been done by an accountant using the study theories of accounting from accounting philosophy science. A job is said to the profession if especially closed to the public generally because people who were in the sphere of the profession need to have gotten special education in the field of the profession. Accounting which essentially is a form of an interpretation of corporate finance for measuring and outlines a certainty about the information pertaining to cash flow of company finance, relating to that profession, needs an act of ethical inevitability, remember people involved in it is lookout for an ethical value to avoid the possibility of defect ethical who would destructive of accountant integrity. By approaching the axiology who heuristic, this paper will underline the role of ethical and accountant strategic in today global area.
\end{abstract}

Keywords:

Accounting, Ethics, Primacy Of Moral

\section{Introduction}

In understanding which has been widely circulated, and of course have been known by public, accounting purposes can be framed in two understanding: namely (1) provides information on corporate finance that can help in making an estimate of potential corporate profits and (2) provide information about the change in economics source, include asset, debt and equity. Both this understanding, by the accountants in his work usually embodied in a move to provide 
information in the form of a report which contains, financial position, the output and changes in other financial position was properly in accordance with Prinsip Akuntansi Berterima Umum (PABU) or Generally Accepted Accounting Principles (GAAP).

The provision of information in the form of the report, with respect to the performance of accountant, all this time of course been aware of the existence of a code of conduct professional accountant set by the Ikatan AKuntan Indonesia (IAI), as ethical guidelines that clouds the accountants doing their jobs. Ethical guidelines or clouds that is exactly as necessary, considering the accountant is someone who because of education and skills "closed" for the / other parties (read: not everyone can be called accountant). Because "their closedness", hence it is understandable why IAI issued a code of conduct professional accountant. On hand this, code of conduct accountant professional it is that in perspective ethics known as the name of ethics profession, have been the inevitability of remember the code of conduct professional accountant essentially set internally the performance of the accountants to behave ethically. Some time ago happened many cases pertaining to transgression, accountant professional ethics for example:

- cases andersen public accountant and enron was revealed at enron register the destruction bankruptcy to court on the 2 December 2001. At that time, is debt companies reported, that causes investment value and operating profit are the same reduced in numbers.Before bankruptcy enron revealed, andersen public accounting maintain enron as clients company, by manipulating financial reports and documents for enron's destruction bankruptcy;

- September 2001, KPMG-Siddharta Siddharta \& Harsono must be put to shame .The famous public accountant is proven tipped off tax officials in indonesia was around us $\$ 75$ thousand. As a stratagem, published false invoices to KPMG professional service fees owed his client PT. Easman Christensen , baker hughes inc subsidiary . Recorded by New York Stock Exchange ;

- Jakarta 19 April 2001. Indonesia Corruption Watch (ICW) asked police to investigate nine public accountant office, Based on the Financial and Development Supervisory Agency or we called "Badan Pengawas Keuangan dan Pembangunan" (BPKP): allegedly having collusion with the bank had audited between 1995-1997.The coordinator of ICW , Mr. Teten Masduki told reporters in Jakarta, Thursday, express based on BPKP the findings nine of the ten that was audited concerning approximately 36 troubled bank does not check conformity with the Audit Standard.

- Jakarta, Kompas.com - the defendant the piercing cases of citibank fund, Malinda Dee siswowiratmo (49), known transfer the funds some customers by means of falsify the sign of the hands in a form transfer .

- this case happened about years 2004. Mulyana w kusuma as a member of the election commission allegedly BPK members of the board when it was going to do financial audit relating to the procurement of logistics. Election Logistics for the elections meant that the ballot box, the ballot, the envelope, voice, ink and information technology.

- Finance Minister, Mrs. Sri Mulyani indrawati freeze the company public accountant permission Drs Oman Pieters Arifin because it violated auditing 
standard, and Public Accountant Professional (SPAP). The breaking was done in an audit PT. Electronic Solution financial report 2007

- The press board decided, television stations RCTI violated article 1 and article 3 the code of journalistic ethics about clarity a source of information related the news about "alleged the matter leaking of president candidate" presented in the Seputar Indonesia Program at the afternoon on June 112014 , Seputar Indonesia night on June 112014 , and Seputar Indonesia morning on June 122014 .

- cases manipulation financial statements PT. KAI, the treasury said, the financial statements that has audited by S. Manan's Public Accountant.The audit for financial statements PT. KAI in 2003 and previously years have been done by the financial auditing board (Badan Pemeriksa Keuangan) BPK.

According many cases above, Ethics and the positive attitude accountant in Indonesia is one factor to improve the quality of the financial report (yulianti and fitriany, 2005). The accountant may believe that accountant ethical performance is impossible, as with regard to "secret" a ,next the company financial information will be produced. For that reason, the nature of the ethical performance should be more comprehensible in, either by the accountant or by the leaders of a company that was be object of accountant research.

\section{Literature Review And The Focus of Research Ethics}

In the general dictionary, Indonesian Language, ethics is the knowledge science about moral principles. While in the dictionary Echol and Shadaly (1995) ethics was, ethical behavior worth, civilized, and attitude. Discretion Normative, from sight ethics was a series of moral principles that separates a good thing and a bad thing as well as what to do and not to be done by someone (, stead et al 1990 ).While according to Satyagraha (2003:4) ethics was values and morals norm in a society. Because of this ethics are defined as morality. This is in line with the opinions of Boynton and Kell (1996) that define ethics as a institutions consisting of moral principles and standards that focus on human traits to be able to determine "right" and "wrong". So did the other arens loebbecke (1996) see that ethics pertaining to moral device and that the value of that reason, ethics is a principle of morals and conduct on which to base act for someone, so what is he doing valued as a deed of the glorious so as to increase the degree of dignity and honor for a person (Munawir, 1997)

According to brooks (2012), from the perspective of an etymology (the science of the origin of the word), Ethos which means the nature of decency or customary. In a dictionary common Indonesian language, ethics are defined the remembrance of the science of azaz-azaz ( moral ) . From the linguistic it looks that ethics connected with the effort to determine human behavior. As for the meaning of ethics in terms of the term, has been stated in the experts by means of which vary according to this odd vantage point .

\section{The Types Of Ethics}

There are two types of ethics in determining and poor unmannerly good man:

1.Ethics descriptive, ethics which trying to see the critically and rational attitudes and unmannerly people and whatever pursued by human beings in life as something of value. Ethics descriptive giving facts as a basis for come to a decision about unmannerly or attitude will taken.

2. Ethics normative, the ethics trying to designate various attitudes and pattern of ideal 
behavior that should have by human beings in the life of an something we consider. Normative ethical pass judgment and to give norm as a basis and skeleton action will be decided.

In Generally, ethics can be split into:

General ethical, talked about basic conditions how humans act ethically, how humans judge ethical, ethical theories and moral principles became the basic for mankind in act and benchmark in judging good or bad an act.

General ethical can be analogies to science, which discusses a general sense and theories. Special Ethical was the implementation of basis moral principles in a special realm of life. But It is can be Applicated : how i make a point others and my behavior in activity and realm of life and special activities which are based on the way, the theory and moral principles basic .But, the application of it can also tangible: how i think my behavior and others in field of activity and life special triggered by the that allows human acts ethical: how to people take a decision or action, and the theory and behind the moral background principles basic.

Special ethical divided into two parts:

1. Individual ethics, talking about obligation, attitudes and behavior of himself.

2. Social ethics, talking about obligation, attitudes and behavior of a man as a member of mankind.

The Emphasis here that individual and social ethics cannot be separated in real because the duty of all men interconnected with ourselves and as a member of mankind in. Social ethics related with human relations both directly as well as through institutions, (family, community, state) critical attitude to the world philosophy and ideologies also mankind responsibility to the of the surrounding environment.

\section{The Assessment of System Ethics}

The assessment system ethics focus as a science is behavior of good or evil, to merit or deserve. behavior or temper of someone who has become internalized himself, this is called moral or the manners . Manners can be developed in people soul if its should was born in behavior as we called manners. The manners of a was a , of the assessment is from within, since they were in the form of inspiration, aspirations, their faith, until he is born as riil behavior .

The philosophers explained that behavior valued in three level :

1.The first degree, as were born into the work of, so was just a plan in the heart, intentions

2.The second level, after being born into the real work is manners

3.The third degree, resulting from or the action result.

Heart or ordinary intentions also called karsa, or whim his willingness to. The contents of karsa this is what will be realised by deed. In terms of realizing depend on four variable happened:

1. A good purpose, but the way to get there is not good.

2. The purpose were not good, how to achieve it looks nice.

3.Nothing good, and both how to achieve it is not good.

4.good purpose, and how to make it look good too. 
Factors that affect ethical violations

factors that can influence ethical violations:

1. is as follows The needs of individuals like corruption. economic reasons

2.There is no guidelines, grey area, so that there is no. guide

3.Behavior and habits of individual, as the accumulation of bad habits

4. The environment unethical which are affected by the community

5.The behavior of being imitated, the effect that goes too far primordialism

Sanctions Ethical Violations

Received sanctions for a foul ethics are as follows:

1.Socially sanctioned

Small relative scale understood as errors that could be "forgiven"

2.Legal sanction

a large scale, a disservice to the right of other parties. Criminal law

occupy top priority, followed by civil law.

\section{Moral}

The meaning of Moral in terms of languages derived from latin, mores the plural of mos it means adapt, habit. Moral In an Indonesian language dictionary determination of good or bad the act and behavior. For the Next morals in the meaning of terms is a a term applied to determines the boundaries of the nature of, temper, will, opinion that of which efficiently, it can be said right any, good or bad.

Based on quotations above on, also that moral was a term used to people gave ear on the activities of good or bad, true or false. If ethical and moral sense the others connected we can say that between ethical and moral have the same object, the equally discuss all people position next determined whether good or bad. However in some respects between ethical and moral having the difference. If in speech ethics, to determine the value all people good or bad use benchmark as ratio or brain, even moral benchmark used the Norma is growing the place. Thus, ethics is thought more philosophical and be in the concepts, and moral are in the reality and appeared in behaviors that evolved in the community. Thus, the benchmark used in morals to measure human behavior is customs, habits and other which prevail in the community

Ethical and moral the same meaning but in daily use and there is a slight difference. Moral or morality used to act is being valued while ethics used to study moral. Moral awareness and the relation to a conscience that in a foreign language, called nurani conscientia, gewissen, geweten, and arabic language qalb, called fu' ad.

In consciousness moral includes three point, feeling to or compulsion to do an ethical action. Second, awareness from moral can also rational and objective, what in general acceptable by the community, as a thing can be implemented universally objective or, and can approved against every time and place for any person who is similar in real-life situations. Third, moral awareness can also appear in the form of freedom.

Based on the description above, it can be concluded that moral more reference to a value or system life implemented or enforced by the community. Value or system is believed to be living by community as to be encouraging the emergence of happiness and peace .value is Copyright (C) GLOBAL ACADEMIC EXCELLENCE (M) SDN BHD - All rights reserved 
required with regard to feelings, rational, generally and freedom .If that values was internalized in person him self, so moral will form their own . the people like that discharge will easily could do a deed without there should be encouragement or pressure from outside.

\section{Profession}

According to Agoes (2006), professional terms have been understood by many that pertaining to the highly influenced by education and skills. But with the skills it obtained from vocational education is not enough called profession. But should be mastery of systematic theory underlying the implementation of, and relations between theories and application in practice.

The profession Characteristics

In general there are some features to or of the nature of, attached to a profession namely the special knowledge, :

a. usually inventiveness and skill are owned by, education training and experience. years

b. the rules and moral standards high.It is usually every owner of a profession based its operation in. professional codes of conduct

c. to serve the public interest every professional managers to put self-interest under public interest

d. have the permit for the specialized to perform a profession.

Every professional will always, relating to the interests of the community where humanitarian values such as safety, , security survival and, etc hence to run a profession must first have the permit for the special

e. The professional usually becomes a member of a profession . By seeing the common professional above, we can conclude that the professional are benchmark behavior that is above average. On the one hand there is a demand the very heavy, but on the other hand there is a clarity about pattern of behavior that well in order public interest. If all walks of life and applying a field of activity, high professional standards will have to expect a public quality the increasingly good.

\section{Professional Ethical Principles}

1. The responsibility

a. with the implementation of the work and of the results .

b. appraisal of the impact of a profession that is for the lives of others or the community at large .

\section{2 .Justice}

this principle require us to bestows just do what they are entitled to .

\section{3 . Autonomy}

This principle autonomy demanded that professional all the people have and give freedom in running profession .

\section{The Role Of Ethics In A Profession}

The value of ethics is not only belonging to one or two people, or a party person only, but belonging to every community groups, even the smallest group of family up to a nation. Following that value of ethics, a group is expected to have values to set a life together. One of the people will have values who became the basis of the association good with group or society 
in general and with fellow members, namely the public. Professional. This group often takes centre stage because of the values governing and set out in writing (profession code of conduct) and is expected to hold on its members.

Community grew to clear when member's behavior of a profession that is not founded on values approved by (way with set out in the professional codes of conduct), so there to the deterioration of conduct the profession. For example is on the legal profession known the Mob Justice also similarly at doctor profession of a super clinic establishment at the fancy community so the poor impossible reaching for it.

Hence can be concluded that a profession can only gain the confidence of the community, when the inside of the elite professionals that there are strong awareness to heed ethics profession at the time they want to give the services of professional expertise to the people who need it. Without ethics profession what once known as a an honorable profession will soon fall relegated to a job the search for a living ordinary occupational who shall not tinged with value of idealism and the end will end up with the absence of more respect and trust that appropriate given to these professionals elite

Ethical Principles Implementation of Ikatan Akuntan Indonesia (IAI) :

1. Responsibility of Implementation

As professional, members have significant roles in society. The role, in line with the members have a responsibility to all users professional services. Members must always responsible to cooperate with a fellow member of accounting to professional development, of public trust, and do the responsibility of profession in manage on their own. Effort Collectively all members of business required to maintain and improve the profession.

2. Public interest

Every member of to act in the service to the public, respect public trust, and demonstrate a commitment for professional.

3. Integrity

The integrity of is an element of the underlying character that emergence of professional recognition. Integrity is the quality of underlying the public trust and is the basis of (benchmark ) for members when they take the decisions. The integrity of members make they have to requires other things, being honest and forthright without having to sacrifice service recipients' secret

4. Objectivity

The objectivity is a quality of being put a value for members services. The principle of objectivities requires members be fair, impartial, honest intellectually, not prejudiced or bias, as well as free of conflict interest or are under the influence of other parties.

5. Prudence

Professional prudence requires members to meet professional's responsibilities with competence and perseverance. This connote that members have an obligation to carry out professional services as well as according to their ability, in the interest of users and consistently with professional responsibility to the public 


\section{Confidentiality}

Any member of the need to respect the privacy of information obtained during perform the services of professional and cannot wear or reveal information that without approval unless they have the right or duty of professional or legal. to verbalize

7. Consistency

Consistency is the concept in accounting demanding standards apply continuously not be changed with justifiable cause.

8. The technical standard

every member must carry out his professional services in accordance with the technical standard and relevant professional standards. In accordance with his expertise and carefully, a member of have an obligation to carry out the commissioning of a receiver during the service was in line with the principle of integrity and objectivities. The technical standard and professional standards that must be obeyed with member is a standard issued by lkatan AkuntanIndonesia, the international federation of accountants, governing body and relevant regulations of legislation.

Hence even be concluded that a profession can only be the trust of the community, when in the elite professional is strong awareness to heed ethics profession when they wanted to provide services professional expertise to the people who need it.Without ethics profession, what was once known as a profession honored will soon fell relegated to a job search a living usual (occupation)) who will not tinged with value of idealism and the end is no longer respect and trust worth given to the this elite professional.

\section{Behavior Accounting}

One of the branches of the accounting is bahavior accounting is focused on the relation between human behavior and an accounting system. Many people realize that the accounting process including the summarizing of some economic happen is the impact of human behavior and that accounting measurement that operates using factors influencing the behavior and this does not determine success or economic activities. Behavior Accounting science see a fact that occurs in a agency relating to behavior employees these agencies. Behavior Accounting the same with parent science discipline. The science is applied and practices. This science use the result of the parent science discipline to explain and predicts human behavior.

Ikhsan ( 2005 ) in Putri ( 2008 ) mentioned that the purpose of behavior science is to understand, explained, and predicts human behavior to a generalization that set about human behavior supported by empirical gathered in an impersonal manner through open procedures, good to review also replication and the verifiable by interested other scientists

Behavior Accounting give a frame of are arranged based on to technique to understand and measuring the impact of business process and institutions performance for measuring and reported behavior and relevant opinions to strategic planning and to affect opinions and behavior to ensure the success of the business policy implementation. Behavior Accounting also see the relation between human behavior and accounting. behavior accounting also on how influence can be changed by the change of era or style brought and how accounting report and procedures can be used effectively to help individuals and the organisation attain their goals. 


\section{Research Methodology}

Methods used in this study is a study literature, with blends a result of some the done before which is relating to ethics, behavior accounting and sciences philosophy and psychology, or in science philosophy better known for his heuristic axiology approach.

According to Carrad, a heuristic is the first step, as a find sources activity get data, or material history or history evidence (Sjamsuddin, 2007: 86). A heuristic is the first step in the writing of history and data collection as much as possible to used as a source of research history through the Interview, observation, interpretation, documentation, histography.

Axiology found inside his book Jujun.S.Suriasumantri philosophy of an introductory popular theory that axiology defined as relating to the value of knowledge getting in. Value to be owned by human being to perform many considerations about what is judged. So approach that heuristic axiology's is an approach in order to get value with the usefulness of science activities for or data sources as much as possible to be. research

\section{Results and Discussion}

\section{Moral and Accountant Professional Ethical}

With regard to the nature of the performance of ethical has mentioned above, in in perspective ethics always be a role at least two the following factors .On the one hand, there are existing norms and moral values are according to general in nature, and on the other hand there is a special situation which according to specific nature.

In the context of the accountant world ethical performance can be realized through amalgamation of two factors (cf.Bertens,2001). This effort must be underline, remember accountant performance ethical essentially manage the people (in the company context), good accountant itself of individuals has idealistic and people itself in the company that are part of company institutional. This relationship, can be realized through three things, norm of moral, law, professionalism. But, concretization the third are always has constraint with the dialetic things. Dialectics is arising, this kind of according to peursen ( 1976 ) in principle ethics not only the regulations, philosophy and norm as if unchanging, but while arising critical questions came on for example how humans must responsible to report of result performance

In other discernment, peursen to affirm that ethics will be able to overcome, concrete cases as confidence religious, the government policy in all things, and community democratization, or anything related to the company, as long as it done through dialectics. Through dialetics the accountant will continuously open to all possible contained in a new development. In this context, the importance of ethical awareness for accountant in finding its relevance, so that freedom existentially as professional accountant keep well maintained

Keep the accountant extential freedom, it is very important thing for the accountant today, in the middle tsunami information and fear of development information technology. It is because , although Indonesian have highlighted that ethics nation and good citizenship is based on values ethical Pancasila, does not mean Indonesian accountant people today realized roots their ethical clearly. When as public knowing, accountant idealism often dialetic with the spirit of commercialism and consumerism who do live real among the community today .For 
example, who has recently cases of financial reporting of Garuda who reported that net income escalated compared with of the previous year (okezone.com, friday at 28 june 2019). This case also involved public accountant affiliation big four, in this very clearly offense ethics either directly or indirectly.

If the reality in our refer to the its cultural of relativism, rachels (2004) said, may be able to understand why many of us easily believe that no truth objective in morals, as a different culture believed to have also different moral code. This means that, treatment can happen it to a company in the different area have also different moral code .But, affirming in connection with Indonesia ethical performance for an accountant, expected rooted in pancasilas'value, the critically rachels'principles has to be understood, because basically moral's norma always universal. Is human nature be besieged always want to be protected by morals 'Norma in order to find truth, good, and beauty held in life and living.

If want to tune in, today freedom expressed the mind and opinions in accordance with conscience, including also the right get the information, so perceived as a human rights most essential in order to implement justice and righteousness, the advancement of general welfare , and in order to educate life the people. Human rights most essential the democratic a reflection of life a nation. In Indonesia, especially since the era of reformation 1998 , democratic life is clear that reflected in the life of our society, especially if we watching for how social media the (consequence of the development of terrible communication and information technology) life among us to fiercely. This fact ,so attributed closely (instead of influential) with the performance of ethical accountant, with respect for the purpose essential accounting itself, which are ( 1 ) provide relevant information; (2) convey information whose truth valid and highly capable; (3) To provide information that is easily understood by all interested parties (4) submit financial reporting for the benefit of all parties related with company activities; (5) provides the real time transaction information (as soon as possible) in accordance with general accounting accepted principles and can be compared and; (6) submit financial reporting conveyed completely and comply with the disclosure of financial reports .

Besides that, the professional of accountant had an profession organization whose particular importance and was a member of the board of the world professional accountant organization as international federation of accountants (IFAC) and become international professional organization partners as ICAEW , CPA Australia , ACCA and so on , so that the adoption and development of standards, rules and codes of conduct of professional accountant has been developed on the basis of reference is complete and quality .

For that reason, with respect to the above, the performance of ethical accountant Indonesia today can be expressed as an equation that will, because the ethical performance was loaded containing professional freedom (especially in expressing the thoughts and opinions related to financial reports ). This may it is noteworthy, having been mandated by article 28-f 1945 constitution: "everyone has the right to communicate and get personal information to develop social and environmental and is entitled to locate, getting, having, store, process , and convey information using any kind of the existing ". Implications of this, the performance of ethical accountant said laden containing professional freedom apparently show the red with human rights in universal .But the freedom ideal of freedom and institutionally different accountant in 
other countries, because Indonesian accountant rooted in the ethical value of pancasila and UUD .

Remember the purpose of essential accounting as providers of information in the form of a report which contains, financial position, profit and loss, and changes in other financial position was properly in accordance with GAAP or PABU can not be denied how is accountant demands on the understanding of freedom of his profession as has already mentioned, and against problems that pertains to the value of nations ethical and with ethics profession itself. Even, can be assert, the understanding about value of nations ethics nations and profession ethics, made an accountant can be called competence or expert.

In chronological order how the ethics for the accountant can attributed the closely with state ethical values, now very often we heard term good corporate governance known as good corporate governance (GCG ) can be derived into the good governance for various institutions to for the government. So the codes of conduct can be derived in the professional conduct in company (code of corporate and business conduct) an implementation of any one principle good corporate governance (GCG), in code of conduct \& amp; the company employees are required to implement the ethics business practices in all cases conducted in the name of their agency or corps. When principles were rooted in the culture have agencies or company (corporate culture), employees \& CEO the company will probed leaders trying obey " which may" and "which no " done in company business activity. Encroachment upon codes of conduct is serious, category and violation of law.

However, freedom of the accountant is not just an absolute and can be done in liberal, but rather something must be accompanied with awareness of the importance of ethics Norma, professionalism, and law of supremation. It is explicitly stipulated in the code of conduct professional accountant consisting of 3 ( three ) an important part:

Section A: basic principles of ethics

Section B: accountant professionals in public practices

Section C: accountant professionals in business

So that it can be concluded that when accountant choosing practiced as the company public accountant and business in as the company still needs to adhere to the terms of the code of conduct accountant, that accountant personally or in corps practiced in order to contribute to the practice of good corporate governance in order to achieve the state's purpose .

Thus, can be expressed the Indonesian accountant ethical performance basically in rhythm with "enforcement of Indonesian accountants ethical norm" whose source in values of Pancasila and UUD 1945, remembering (a) progress of the interpretation of limitation the profession ethic norm attributed to the spread of the values global today, and (b) the appearance of efforts construction the fact/data recalling to function Indonesian accountant always use of language as his strategy in communication , meanwhile we know just that basically speaking those also reflection his campaign in construction a fact or reality by a particular purpose to other parties (an opponent or partner in his voice) .

The government also has set about public accountant clearly, practices for example the government regulation no 20, 2015 years which contains the practice, public accountant, 
continuing education to keep public accountant is competent and sanctions ( pasal16) will be given to public accountant if breaking the rules

\section{Freedom Existential and Moral Primacy}

The other if we are talking about freedom of the press, for example, in general seen as freedom of the press given by the government and freedom to the press, (magnis-suseno 2001; haryatmoko, 2003 ), because it natural that the government and the community ensure of press freedom in exercising the functions of essentially. For example, chapter 8 article 18 verse 1 law no. 40 / 1999 on press asserted, "every a person who is unlawfully with unwittingly does the act of that result in impede or hinder the implementation of article 4 ( paragraph 2 and 3 ) condemnation prison at most, two years or fine the most rp 500 million ".However, freedom expression of the press today should be seen critically. It is because, freedom of the press who have been guaranteed by the act of it is basically run in linear with production process press , so that ethical principles journalists have not regardless of human relations. In discernment other, always occurs dialectics who dichotomous between reporters 'idealism and the company press, who often to sacrifice reporters' idealism .

Reporters idealism referring to journalistic as an integral part professional sensor reporter with respect and self control with their communication. This strategy attributed with the reporters today when highlighted, reflect, and then construction a fact or reality through their effort. Meanwhile, company press refer the presses characteristic of industry as a business. Among business practices, idealism and press reporters implementing activities their journalism, the find, having, keep, process, and information to the general public, either in a form of, sound, pictures, sound and pictures, as well as data and charts using the mass media and every kind of available wibowo (, 2009 ). Remember the expression or writing journalism that was spread so widely, to be only natural that reporters required to be according to yourself with ethical principles to avoid the political practices information that leads to a monopoly of the general opinion. This effort must underline, remember the image of the press for Indonesians to grow that strong public opinion. as forming the Easy to spot, the government and society also kelompok-kelompok seemed keen on the control of the press in order to win the race for in communications,

This Efforts, if allowed by press, will trigger ethical problem, when understood that pers function not only as manager, presenter, disseminators, information evaluation, but also as the aspiration places, environment controller, tolls of socialization, recreative facilities, educative facilities.

In that function, undeniable press of ethical responsibility whose weight in it keep his freedom. Hence, to maintain their freedom, reporters is expected to uphold the truth ethos first, because the citizens entitled to accurate, complete, and precise. Hope on the maintain freedom of the press will not come into being without the journalists work hard in upholds the truth ethos (wibowo, 2009).

Illustration regarding reporters above, may together with ethical accountant who and this performance. The truth Ethos, or truth value mark a group, in practice by the integrity it was propped subjective (accountant) or honesty of accountant when construction the fact into the financial reports about the company being "held on". Integrity subjective of accountant in this 
regard should not only importance of their idealism or not in order to favorable accountant office work, but rather refer to the fact that people in the company is active subject which the nature of fight each other over communication strategy that can be displayed in the accountant financial reports.

By the other assertion the people in the company are not just require the information factual and actual pertaining to finance in their employers, but also need aid the accountant in attitude for a fact or possible reality other emerged from the facts presented by the accountant. Hence, as has already been mentioned, understanding of ethical values for accountant is would given the hope of people in the company. And, related to this, it is also questionable how efforts to maintain freedom existential? Accountant In this context, freedom existential resting on the ability of the accountant to determine, himself by means of ignoring, anyone intervening which therefore assumed must be positive. Freedom existential hence not emphasized in free from anything, but is free for what. This means, accountant as called free to choose actions professional, because freedom their selves can get there positive deliberate act .

Meanwhile, according to Bertens in 2004 , existential freedom is highest freedom, freedom that causes men as if "having their self", at having achieved the economic situation of autonomy, maturity, authenticity and ripeness spiritual .Human freely in the existential will therefore in spite of all pressure and alienation, for he able to realize the all of possibilities is independently and creatively. Hence, critically in this relationship can be expressed that accountant freedom existential is impossible released of accountant world existence itself .

Referring to above, and so freedom accountant was being used that means at the same time the accountant must be and involve ethical responsibility to all terms, of them (a) of his own conscience; (b) of their fellow citizens or people in in the company also both have the freedom; (c) for the interests of the general who represented by corporate and the government; and (d) of fellow accountant colleague.

In critical perspective, besides the described above, pertaining to the problem of the rights and duties, also the moral pertains to other people. Seen from the perspective of ethics, according to bertens ( 2004 ), there was the right legal and right moral. The legal right is the right based on law in one form of, , for example the act of the law, other legal and documents. If the country issuing the act of taking special allowances per month for teachers, for example, every teachers receive mercy provided meet specified terms. Meanwhile, right moral, be moral system and therefore only right moral ethical based on the principle and ethics regulations. In relation married couple, for example, is one have right moral affection.

Isnaeni R ( 2017 ) ethic orientation is how person view regarding ethics itself . Ethical behavior someone would influence in decision making when faced with an ethical dilemma .

Forsyth (1980) said that orientation ethics or values ethics controlled by two characteristics namely idealism and of relativism. Idealism is orientation ethics which referring to the degree to which somebody believe that the consequences of act done can occur without breaking moral values. Orientation and ethics of relativism is referring to values (given to the moral) universal guide behavior. 
Thus, can be remember them as a cantilever of ethical responsibility for an accountant, a right moral have highest in human life than the legal right. So, containing the legal right is not necessarily right moral, but the legal right must also is right moral. A director pay low the wages of women workers because there is no rule that hear, the for example, he use legal right. But, he trampling right moral woman workers, for discriminated gender. At the point Moral this is reflected at the other people in connection with you is called man accountant.

Thus, the right supposing that someone free do or to have something, or others may not avoid that someone to do or to have something the .The implications of this, the right commensurate by an obligation others not to do something, is no avoid someone who want to perform or have what they are entitled to. Hence, the right considered correlate by an obligation because discuss rights shall be one breath by an obligation. For example, in the united states since the end of the civil war ( 1860-an ) followed by industrial expansion and financial major ,a business the issuance of newspapers changed from work personal characterless being firm that business characterless.

The impact of the above, rights and obligations reporters can be disturbed, especially because the press did not earlier again conveys their ideas due to the role of the bigger advertising office .the advertising office for example to determine and regulate newspapers with how to do own market research to find advertising it self and my own devising manuscripts and advertisement design.

\section{Summary}

The accountant correlation between rights and duties as mentioned are considered absolute, but Indonesian accountant individual ethical behavior today must be relevant with The primacy of moral effort to gain continuously.

Isnaeni R (2017) challenge ethical behavior to be protected by the organization if they truthy care about survival and competitiveness. What is needed in the complex to give more organization stepped forward and operate with strong culture, positive and do have ethics good

The primacy of moral will encourage other accountant and accounting that problems accounting ethical or accountant professional codes of conduct to source on the fact as follows: our freedom limited at liberty others.

\section{References}

Agoes, Sukrisno. 2006. Etika Bisnis dan Profesi: tantangan membangun manusia seutuhnya. Yogyakarta: AMP YKPN.

Bakhtiar, A. (2012). Filsafat Ilmu.Jakarta: Rajawali Pers

Bertens, K. 2001. Perspektif Etika, Esai-esai tentang Masalah Aktual. Yogyakarta: Kanisius.

Brooks, Leonard J. dan Paul Dunn. 2012. Business and Professional Ethics for Directors, Executives and Accountants. Edisi 6. Mason City: South - Western Cengage Learning. Diakses dari books.google.co.id pada tanggal 25 Desember 2015.

Bucholz, R. A. (1989), Fundamental Concepts and Problems in Business Ethics (Prentice- Hall, Englewood Chiffs, NJ)

Forsyth, D.R, (1980). "A Taxonomy of Ethical Ideologies". Journal of Personality and Social Psycology Vol 39. Pp.175-184 
Fraedrich, J.P.\& Ferrel, O.C (1992a), Cognitive consistency of marketing managers in ethical situations, Journal of Academy of Marketing Scirence, 20,245-252

Gellerman, S.W.(1986), "Why "good"Managers Make Bad Ethic Choices, Harvard Business Review (July August),pp 85-90

Haryatmoko. 2003. Etika Politik dan Kekuasaan. Jakarta: Penerbit Buku Kompas.

Ihyaul Ulum M.D. (2009). Audit Sektor Publik, Suatu Pengantar, Jakarta:PT Bumi Aksara

Ikatan Akuntan Indonesia 2016,Kode Etik Akuntan Profesional, IAI: Jakarta

Khomsiyah dan Nur Indiantoro. 1998. "Pengaruh Orientasi Etika terhadap Komitmen dan Sensitivitas Etika Auditor Pemerintah di DKI Jakarta" Jurnal Riset Akuntansi Indonesia vol.1 Januari hal 13-28

Magnis-Suseno, Franz. 2001. Kuasa \& Moral. Jakarta: Gramedia.

Mispiyanti,2016 peranan Etika Profesi Dalam Prilaku Akuntan, Jurnal Fokus Bisnis, Vol.15, No.01, Bulan Juli 2016. Page 27

Mc Manara, C. (1999), Complete guide to ethics management: An ethics tool- kit for managers.

Mookherjee, D. and Png, I.P.L.(1995), "Corruptible supervisors and law enforces:How should they be compensated?"Economic Journal, 145-159

Peursen, C.A. van. 1976. Strategi Kebudayaan. Yogyakarta: Kanisius.

Peraturan Pemerintah Indonesiano.20 tahun 2015 tentang Akuntan Publik

Putri, I G. A.M, Asri, Dwija. 2008. Implikasi Riset Akuntansi Keperilakuan Terhadap Pengembangan Akuntansi Manajemen. Jurnal Ilmiah Akuntansi dan Bisnis. Vol.3. No. 2. 1-17.

Rachels, James. 2004. Filsafat Moral. (Penerjemah: A. Sudiarja). Yogyakarta: Kanisius.

Rapar,.Hendrik. (1995). Pengantar Filsafat.Yogyakarta: kanisius

Rosyida,I.,A. (2017) Perilaku Etis Dan Tidak Etis Oleh Akuntan Dalam Sebuah Organisasi Universitas Islam Darul 'Ulum Lamongan, Jurnal Ekonomi Universitas Kadiri (23-38)

Satyanugraha, Heru. 2003. Etika Bisnis: Prinsip dan Aplikasi, Lembaga Penerbit Fakultas Ekonomi Universitas Trisakti, Jakarta.

Sulastri. Putu. 2010. Akuntansi Keperilakuan Terhadap Pengembangan Akuntansi Manajemen . Dharma Ekonomi. Vol. 17. No. 32. 1-16.

Susanto. (2011).Filsafat ilmu: suatu kajian dalam dmensi ontologis, epistemologis, dan aksiologis. Jakarta: Bumi Aksara

Wibowo, Wahyu. 2009. Menuju Jurnalisme Beretika. Jakarta: Penerbit Kompas

Yulianti dan Fitriany. 2005. Persepsi Mahasiswa Akuntansi Terhadap Etika Penyusunan Laporan Keuangan. Makalah Simposium Nasional Akuntansi, Vol.8. 